\title{
Low-Cost Alternatives for Conventional Tissue Culture Media
}

\author{
Dipak D. Kadam ${ }^{1}$, Amit A. Chhatre ${ }^{1}$, Shivaji A. Lavale ${ }^{2 *}$ and Nalini A. Shinde ${ }^{1}$ \\ ${ }^{1}$ Lokmangal College of Agricultural Biotechnology, Solapur, MS, India \\ ${ }^{2}$ International Crops Research Institute for Semi-Arid Tropics, Hyderabad, India
}

*Corresponding author

\begin{abstract}
A B S T R A C T
Keywords

Low cost medium, MS medium,

Micropropagation, Tissue

culture, Cost

effectiveness

Article Info

Accepted:

20 March 2018

Available Online:

10 April 2018

The low cost alternative components of tissue culture media were evaluated for their potential to supply nutrients and to support growing explant of Banana cultivar in vitro for their cost effectiveness against conventional high cost media. The Murashigeand Skoog (MS) salts and sucrose were replaced by vermicompost $(50 \mathrm{~g} / \mathrm{L})$, table sugar $(30 \mathrm{~g} / \mathrm{L})$ and coconut water $(70 \mathrm{ml} / \mathrm{L})$, and agar was replaced by filter paper, sand and wheat floor. The conventional MS medium supplemented with $30 \mathrm{~g} / \mathrm{L}$ sucrose and $8 \mathrm{~g} / \mathrm{L}$ agar was used as control. A banana cultivar was regenerated on control and combinations of alternative components. MS salts in combination with filter paper as solid matrix was found as very efficient for shoot induction, multiplication and root formation with reducing the cost upto $58.13 \%$.Vermicompost as nutritive source was found to be very effective in reducing cost of media per plantlet. Table sugar reduced the cost of carbon source drastically by 97 $\%$.Use of such alternatives can reduce the cost of media thereby minimizing the production cost of tissue cultured plantlets.
\end{abstract}

\section{Introduction}

The demand for high-quality, high-yielding, disease-free planting material has increased significantly over the last two decades with increasing demand for agricultural, forestry, horticulture products. Plant tissue culture has emerged as an important biotechnology and commercially viable tool to generate this high quality, disease free and high yielding planting material rapidly in the laboratory irrespective of the season. At present, there are around 200 commercial tissue culture laboratories in India with gross production capacity of about 500 million plantlets per annum. Banana, Sugarcane, Apple, Pineapple, Strawberry,
Gerbera, Anthurium, Lillium, Orchids, Bamboo, Date Palm, Teak and pomegranate are some of the major plants tissue cultured in India.

Micropropagation is a vegetative propagation of plant under aseptic conditions. It can be used to produce disease-free plants by excluding disease-causing organisms during the propagation cycle. The major advantage of micropropagation is the extremely high multiplication rates. Therefore, this technique is highly suited for rapid multiplication of genotypes. An often-cited disadvantage of modern plant tissue culture methods is the relatively higher costs involved as compared 
to other methods (Sahu and sahu, 2013). The need for low-cost plant tissue culture systems, applicable for micropropagation has been emphasized to allow the large-scale application of such technology in developing countries. The use of chemicals such as carbon sources, gelling agents, inorganic and organic supplements, and growth regulators in culture media, make this technique expensive. Sucrose is usually used as a source of carbon and agar as the gelling agent, and together they constitute the most expensive components of the culture media. In this study our objective was to evaluate low cost alternative media (LCM) for shoot induction, shoot multiplication, root induction and hardening of banana explants, along with its cost effectiveness.

\section{Materials and Methods}

The tissue culture work was carried out in the Tissue culture laboratory of Lokmangal College of Agricultural Biotechnology, Solapur, MS, India.

\section{Plant material}

A locally available cultivar of Banana (Musa cavendish) which is widely grown by smallholder farmers in Maharashtra state, India was used as source material for this study. The plants were maintained in shadenet for use as source of explant.

\section{Media preparation}

For preparation of medium different low cost ingredients were used. Vermicompost along with table sugar (3\%) and coconut water (7\%) was usedas alternative to conventional MS salts whereas filter paper, sand and wheat flour was used instead of agar as solidifying agent. Standard MS medium with agar was used as control for all the treatments (Table 1). The prepared medium along with control was sterilized in autoclave at $121^{\circ} \mathrm{C}$ temperature and $15 \mathrm{lbs}$ psi pressure for $15 \mathrm{~min}$.

\section{Sterilization and preparation of banana explants}

All banana suckers were washed in running tap water for 20 minutes. The outer layers were removed from the pseudostems to remain with the shoot tip meristem which, was excised. Explants were kept in $1.5 \%$ citric acid for 30 minutes. They were surface sterilised in $70 \%$ ethanol for 1 minute and rinsed five times in sterile distilled water. To prevent oxidation of phenolic compounds, the trimmed explants were stored in antioxidant solution $(100 \mathrm{mg}$ ascorbic acid per litre of sterile distilled water) till the explants were taken in laminar air flow chamber for inoculation. Before culturing, trimmed explants were soaked in a solution of Carbendazimsolution $(5 \% \mathrm{~W} / \mathrm{V})$ for $20 \mathrm{~min}$. Then the outermost layer of sucker surface was removed and the explants were immersed into $0.5 \%$ mercuric chloride for $5 \mathrm{~min}$. Again outermost layer of sucker was removed and rinsed with $70 \%$ ethanol for one minute. A vertical cut was given and the explants were inoculated in the shoot induction media so as to expose their meristematic region to the media. 6-BAP (4 mg/L) was used as source of Cytokinin for shoot induction in all alternative media as well as control. One explant was cultured in each culture bottle (Fig. 1) and this was replicated 20 times. Cultures were incubated at $26 \pm 2{ }^{\circ} \mathrm{C}$ at $16 \mathrm{hr}$ of fluorescent tube light and $8 \mathrm{hr}$ darkness. Observations of morphological appearance were taken on $20^{\text {th }}$, $40^{\text {th }}$ and $60^{\text {th }}$ day.

\section{Shoot multiplication}

Shoots having uniform size, from same cultures were sub-cultured on shoot multiplication medium containing $0.5 \mathrm{mg} / \mathrm{L}$ IAA. The number of shoots produced per explant and shoot length was recorded on $20^{\text {th }}$, $40^{\text {th }}$ and $60^{\text {th }}$ day. 


\section{Rooting}

Healthy and well established shoots were transferred to rooting media containing $0.5 \mathrm{mg}$ /L IBA, $0.5 \mathrm{mg} / \mathrm{L}$ NAA and $0.05 \%$ activated charcoal. The cultures were incubated at $26 \pm$ $2^{\circ} \mathrm{C}$ and 16 and $8 \mathrm{hr}$ light and darkness, respectively. The number of days to root initiation was recorded. The number of roots, length of the roots and number of leaves was recorded after three weeks.

\section{Acclimatization and transfer of in vitro banana plantlets}

The culture bottles were kept open in the shade net for two days for primary acclimatization. The plantlets were then removed and roots were washed with sterile water to remove all the media from the roots. Then the plantlets were planted in mist chamber in coco peat for hardening for 21 days. The survival percentage during hardening of the plants and number of leaves was recorded to assess the success of the protocol of using alternative low cost media.

\section{Data analysis}

The data was analysed using Analysis of variance (ANOVA) in Microsoft Excel at 5\% significance level.

\section{Results and Discussion}

\section{Shoot induction}

The response of the explant was found to be different to the different types of media and gelling agents (Table 2; Fig. 2). In case of control the growth of explant was healthy and started shoot generation within 40 DAI. Explant growth in Vermicompost and Agar (LCM-1) was also found to be healthy but start of shoot generation was extended to more than 40 DAI. In case of filter paper as a gelling agent, explant grew well in MS salts as well as Vermicompost which was comparable to control. Contrastingly, in case of media with Sand and Wheat floor as gelling agent, explant could not grow and characteristic browning of tissue was observed leading it to fail at in the beginning itself.

There was no significant difference for number of shoots per explant and shoot length between control and LCM 2 (Table 3) suggesting the ability of filter paper to support and to supply the nutrients to the explant as good as agar. Interestingly, growth of shoot was not halted, but delayed, in any of the LCM treatment. Other treatments were significantly different than control.

\section{Root induction}

Though the number of roots was lesser than control, shoots in LCM2 had longer roots and equal number of leaves per plant (Table 4). Root length and number of leaves in LCM1 were not significantly different than control, which indicate its potential in root induction. In case of LCM3 root growth was not at all induced.

\section{Primary hardening}

Survival percentage of plants in LCM, though significantly different, was comparable to the control (Table 5; Fig. 3). Number of leaves in all the treatments was not different significantly. Plants in all the treatments were healthy.

\section{Cost comparison}

Cost of the media in case of LCM1 and 2 reduced drastically as compared to control by $57.15 \%$ and $58.13 \%$, respectively (Table 6). 
Fig.1 Explant culture on different media

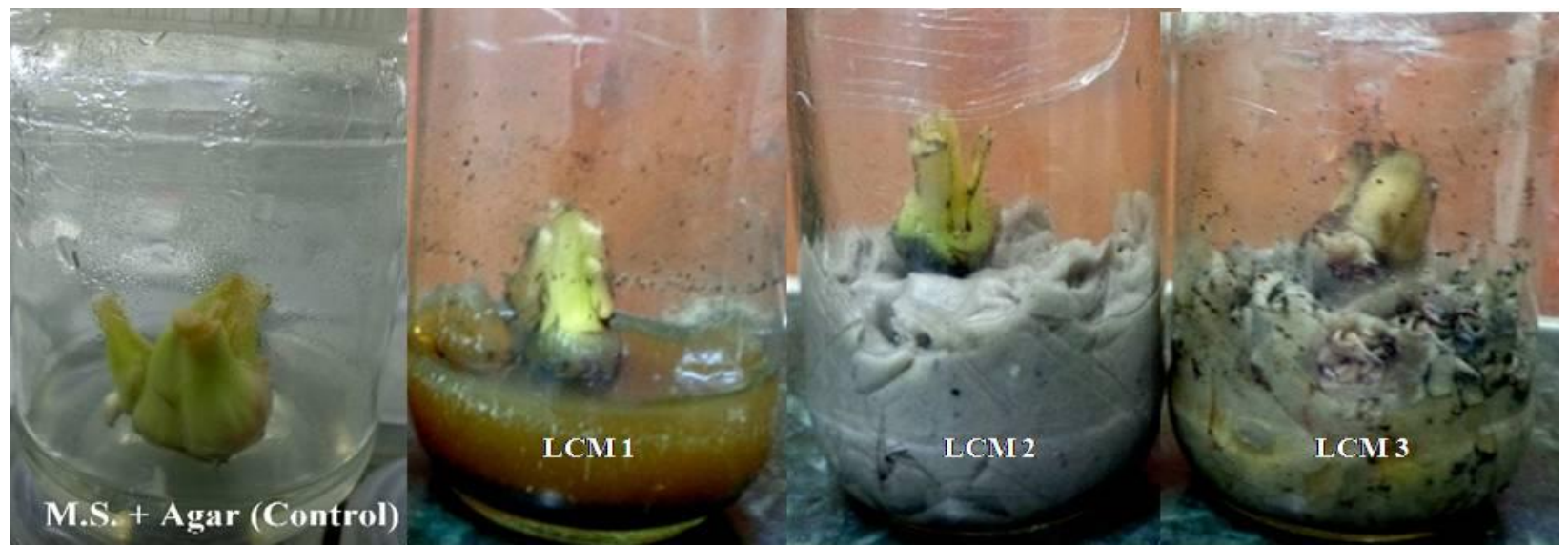

Fig.2 Shoot multiplication

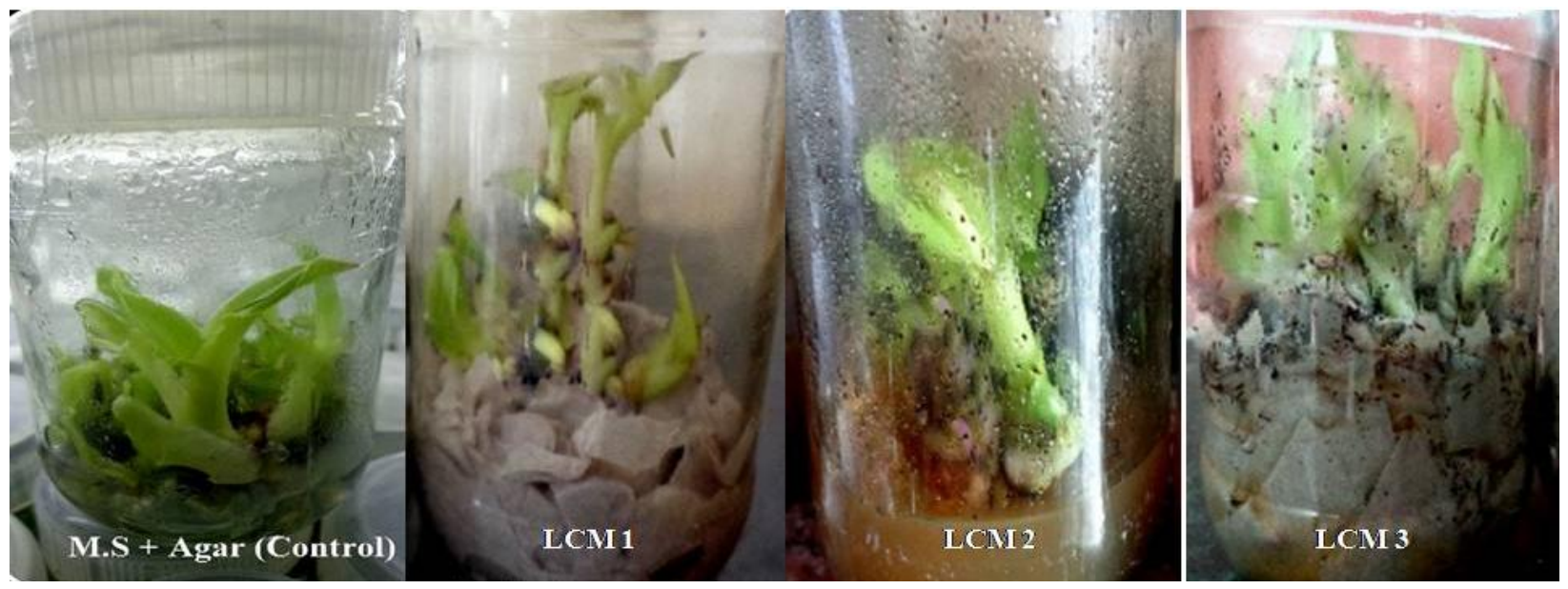

Fig.3 Primary hardening of plantlets generated on different media
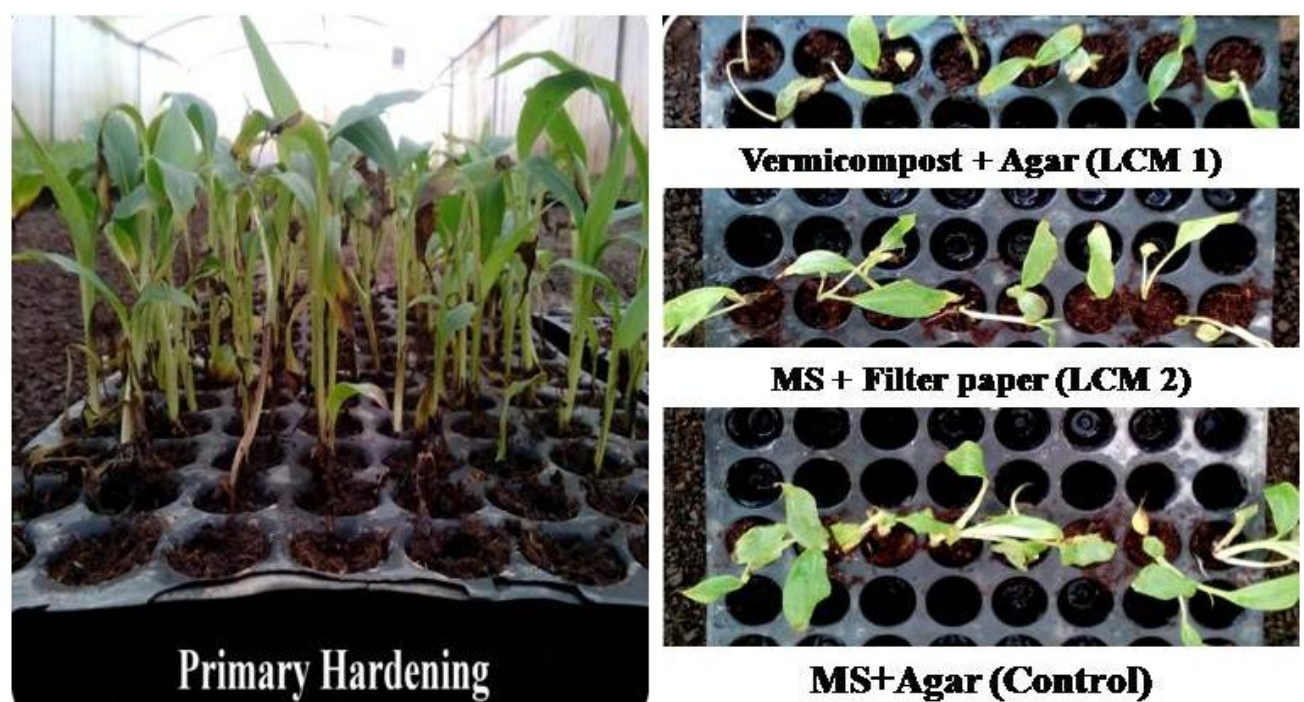

Vermicompost + Agar (LCM 1)

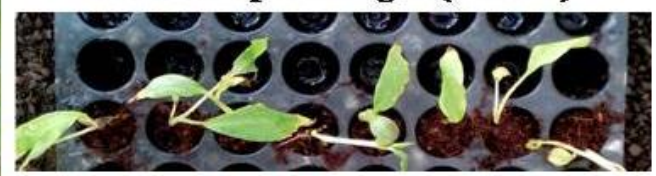

MS + Filter paper (LCM 2)

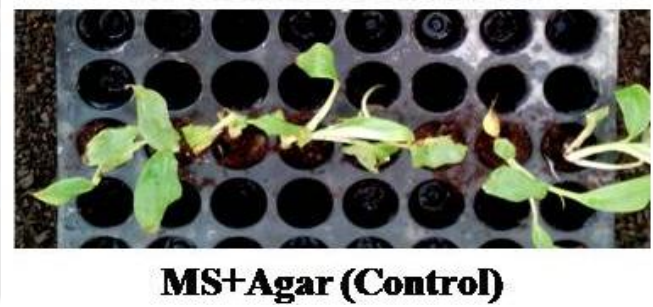


Table.1 Compositions of media

\begin{tabular}{|c|c|c|c|}
\hline \multirow{2}{*}{$\begin{array}{l}\text { Sr. } \\
\text { No. }\end{array}$} & \multirow{2}{*}{$\begin{array}{l}\text { Name of } \\
\text { medium }\end{array}$} & \multicolumn{2}{|r|}{ Ingredients } \\
\hline & & Nutrient source & Gelling agent \\
\hline 1. & Control & MS salts $(1 \mathrm{X})$ & Agar \\
\hline 2. & LCM - 1 & Vermicompost $(5 \%)$ & Agar \\
\hline 3. & LCM - 2 & MS salts (1X) & Filter paper $\left(1 / 3^{\text {rd }}\right.$ volume of culture bottle $)$ \\
\hline 4. & LCM - 3 & Vermicompost (5\%) & Filter paper $\left(1 / 3^{\text {rd }}\right.$ volume of culture bottle $)$ \\
\hline 5. & LCM - 4 & MS salts (1X) & Sand $\left(1 / 3^{\text {rd }}\right.$ volume of culture bottle $)$ \\
\hline 6. & LCM - 5 & Vermicompost $(5 \%)$ & Sand $\left(1 / 3^{\text {rd }}\right.$ volume of culture bottle $)$ \\
\hline 7. & LCM - 6 & MS salts (1X) & Wheat flour (20\%) \\
\hline 8. & LCM - 7 & Vermicompost (5\%) & Wheat flour (20\%) \\
\hline
\end{tabular}

Table.2 Response of the explant to different growth medium

\begin{tabular}{|c|c|c|c|}
\hline \multirow[t]{2}{*}{ Medium } & \multicolumn{3}{|c|}{ Observations } \\
\hline & 20 DAI & 40DAI & 60DAI \\
\hline Control & $\begin{array}{l}\text { Explants remained green } \\
\text { and with healthy growth }\end{array}$ & Shoots generated & $\begin{array}{l}\text { Development of multiple } \\
\text { shoots }\end{array}$ \\
\hline $\mathrm{LCM}-1$ & Explants remain green & $\begin{array}{l}\text { Explants remain green } \\
\text { and enlarged slightly }\end{array}$ & Shoots generated \\
\hline LCM - 2 & Explants remain green & Explants remain green & Shoots generated \\
\hline LCM - 3 & Explants remain green & Explants remain green & $\begin{array}{l}\text { Explants remain green } \\
\text { and enlarged slightly }\end{array}$ \\
\hline LCM - 4 & $\begin{array}{l}\text { Explants remain green } \\
\text { only in central portion, }\end{array}$ & Browning of explants & - \\
\hline LCM - 5 & Browning of explants & - & - \\
\hline LCM - 6 & Browning of explants & - & - \\
\hline LCM - 7 & Browning of explants & - & - \\
\hline
\end{tabular}

*DAI- Day after Inoculation

Table.3 Shoot induction response to different growth medium

\begin{tabular}{|l|c|c|c|c|c|c|}
\hline \multirow{2}{*}{ Medium } & \multicolumn{2}{|c}{ Number of shoots per explant* } & \multicolumn{3}{c|}{ shoot length\# (cm) } \\
& 20 DAI & 40DAI & 60DAI & 20 DAI & 40DAI & 60DAI \\
\hline Control & $5.7 \pm 0.15$ & $9.1 \pm 0.31$ & $9.2 \pm 0.39$ & $3.81 \pm 0.17$ & $4.49 \pm 0.13$ & $4.72 \pm 0.21$ \\
\hline LCM - 1 & $4.5 \pm 0.27$ & $5.4 \pm 0.16$ & $5.4 \pm 0.27$ & $3.07 \pm 0.14$ & $3.47 \pm 0.16$ & $3.55 \pm 0.12$ \\
\hline LCM - 2 & $5.5 \pm 0.17$ & $7.2 \pm 0.25$ & $7.2 \pm 0.42$ & $3.84 \pm 0.11$ & $4.19 \pm 0.20$ & $4.25 \pm 0.19$ \\
\hline LCM - 3 & $3.7 \pm 0.15$ & $4.42 \pm 0.17$ & $4.7 \pm 0.15$ & $3.23 \pm 0.12$ & $3.38 \pm 0.11$ & $3.47 \pm 0.10$ \\
\hline
\end{tabular}

*Mean of 10 replications; \#Mean of length of all the shoots developed on 5 explants 
Table.4 Root induction response to different growth medium

\begin{tabular}{|l|c|c|c|}
\hline $\begin{array}{c}\text { Name of } \\
\text { medium }\end{array}$ & $\begin{array}{c}\text { Number of roots per } \\
\text { plant* }\end{array}$ & Root length\# $(\mathrm{cm})$ & $\begin{array}{c}\text { Number of leaves per } \\
\text { plant* }\end{array}$ \\
\hline Control & $3.8 \pm 0.36$ & $0.4 \pm 0.03$ & $2.9 \pm 0.18$ \\
\hline LCM - 1 & $2.4 \pm 0.27$ & $0.38 \pm 0.04$ & $2.4 \pm 0.16$ \\
\hline LCM - 2 & $3.1 \pm 0.18$ & $0.7 \pm 0.06$ & $2.9 \pm 0.10$ \\
\hline LCM - 3 & 0 & 0 & 0 \\
\hline
\end{tabular}

*Mean of 10 replications; \#Mean of length of all the roots developed on 5 explants

Table.5 Results of primary hardening

\begin{tabular}{|c|c|c|c|}
\hline $\begin{array}{l}\text { Sr. } \\
\text { No }\end{array}$ & Media & $\begin{array}{l}\text { Survival percentage } \\
\text { of plants }\end{array}$ & Number of leaves per plant* \\
\hline 1 & Control & 100 & $3.1 \pm 0.40$ \\
\hline 2 & L.C.M-1 & 85 & $2.8 \pm 0.70$ \\
\hline 3 & L.C.M-2 & 80 & $3.0 \pm 0.27$ \\
\hline
\end{tabular}

*Mean of 10 replications

Table.6 Comparison of cost between MS media and alternative low cost medium

\begin{tabular}{|l|l|c|c|c|}
\hline Sr. No. & Attribute & Control & L.C.M 1 & L.C.M.2 \\
\hline 1. & Cost of media (INR/lit) & 161.24 & 69.09 & 67.51 \\
\hline 2. & No of plantlets generated per litre & $20 / 20$ & $16 / 20$ & $17 / 20$ \\
\hline 3. & Cost reduction (\%) & - & 57.15 & 58.13 \\
\hline 4. & Cost of media per plantlet (INR) & 3.22 & 2.07 & 1.91 \\
\hline
\end{tabular}

This reduction in cost was attributed to replacement of high grade sucrose $(3 \%)$ by table sugar (3\%) which reduced the cost of carbon source by almost $97 \%$.

The carbon source such as grade sucrose that is often used in the micropropagation of plants at laboratory contributes about $34 \%$ of the production cost (Demo et al., 2008). Sucrose has been reported as a source of both carbon and energy (Bridgen, 1994). There are reported success in reducing $90 \%$ cost of tissue culture banana plants by replacing sucrose. In the plant propagation medium Kaur et al., (2005) substituted sucrose with table sugar which reduced the cost of medium considerably by $96.8 \%$ similar to the present study. The findings of our study is in agreement with that of Prakash et al., (2002) who reported the reduction in the cost medium by 78 to $87 \%$ using common sugar.

In case of cost of supporting matrix, filter paper was found to be greatly efficient as it reduced the cost by almost $98 \%$. Both the alternative media were found to be cost effective in contrast with the control. Though, the final number of plantlets obtained in case of alternatives is low, both could generate more number of plantlets when the cost per plantlet was considered.

Alternative media can effectively reduce production cost and hence the research for such alternatives is significant. The use of vermicompost and coconut water as nutrient 
source and that of filter paper as support matrix was found efficient alternative for conventional costly ingredients.

\section{References}

Bridgen, M. P. 1994. A review of plant embryo culture. Hort. Sci. 29: 12431245.

Demo, P., Kuria, P., Nyende., A.B. and Kahangi, E.M.2008. Table sugar as an alternative low cost medium component for in vitro micropropagation of potato (Solanum tuberosum L.). Afr. J. Biotech. 7(15): 2578-2584.

Kaur, R., Gautam, H. and Sharma, D. R. 2005. A lowcost strategy for micropropagation of strawberry (Fragaria nanassa) $c v$. Chandler. Proc. of the VII Int. Symp. On temperate zone fruits in the tropics and subtropics. Acta Horti. pp. 129-133.

Prakash, S., Hoque, M.I. and Brinks, T. 2002. Culture media and containers in low cost options for tissue culture technology in developing countries. Proc. of Tech. in Food and Agricultural, Austria, Vienna.pp.29-40.

Sahu, J. and Sahu, R. K. 2013. A review on low cost methods for in vitro micropropagation of plant through tissue culture technique.UK Journal of Pharmaceutical and Biosciences. 1(1): $38-41$.

\section{How to cite this article:}

Dipak D. Kadam, Amit A. Chhatre, Shivaji A. Lavale and Nalini A. Shinde. 2018. Low-Cost Alternatives for Conventional Tissue Culture Media. Int.J.Curr.Microbiol.App.Sci. 7(04): 2523-2529. doi: https://doi.org/10.20546/ijcmas.2018.704.288 